\title{
Plans for US wind tunnel set to take off
}

Washington. The US National Aeronautics and Space Administration (NASA) seems likely to win funding for the construction of the world's largest and most sophisticated wind-tunnel complex, to be used by aircraft manufacturer Boeing to speed up the development of successors to the Boeing 747 jumbo jet.

A proposal earlier this month by a Senate budget subcommittee to put $\$ 400$ million into the $\$ 2.5$-billion project in the next financial year, beginning in October (see Nature 370, 167; 1994) may be scaled back. But congressional staff say, with broad support within the Clinton administration and both houses of Congress, it will almost certainly open the way for funding to commence in the following year.

The project will involve the construction of huge subsonic and transonic wind tunnels, and is significant because it represents direct support to the US civil aerospace industry. Until now, such support has tended to be indirect, through military and space contracts for example.

A number of industrial companies will use the tunnel. And universities say that the capabilities of the tunnel complex will make it a potentially valuable tool for basic research in aeronautics.

But the facility, to be known as the National Wind Tunnel Complex, will be designed primarily for the convenience of air-

craft development engineers wanting to test and refine aircraft prototypes quickly and methodically. In particular, its main purpose will be to help Boeing to compete with the European Airbus consortium, its only

\section{IMAGE UNAVAILABLE FOR COPYRIGHT REASONS}

nautical engineering department of the University of Southern California, Los Angeles, existing wind tunnels range up to one million, whereas large modern airliners can have Reynolds numbers of 100 million.

The proposed NASA tunnels will be large, but not excessively so - the larger of the two will have a 24 by 21 foot cross-section. Their high price reflects the power and structural strength needed to blow air through them at sufficient speed and pressure, with a minimum of vibration or background turbulence.

Congressional supporters of the tunnel are concerned that US aircraft manufacturers currently rely on European facilities, espe-

rival in the market for large civil aircraft.

The need for the two tunnels was identified in a study carried out last year by NASA, the Department of Defense and other federal agencies to identify important areas of deficiency and overlap in US research facilities. It found no need for extra supersonic or hypersonic wind tunnels, so the proposed complex will be for the development of conventional, subsonic airliners, rather than the supersonic ones which NASA is also keen to support.

The ability to derive useful information on airflow from scale models in a wind tunnel depends on a dimensionless parameter called the Reynolds number.

According to Hsien Cheng, of the aero- cially the German-Dutch wind tunnel at Emmeloord in the Netherlands, for their development work, and are keen that the United States should regain its lead.

"The argument is that the complex will position the US industry to prevail, not merely achieve equity [with Europe]," says Larry Ross, director of NASA's recently established Wind Tunnel Program Office. "The facility would be better than anything else in the world."

The prospect of a new \$2.5-billion hightechnology project has set off a scramble by congressmen and senators wanting it located in their home state. Political and logistical considerations both point strongly to the West Coast.

Colin Macilwain

\section{Soros fund offers helping hand to European agency}

Moscow. The International Sciences Foundation (ISF), set up by the Hungarian-born financier George Soros to support scientists in states belonging to the former Soviet Union (FSU), has offered to help the parallel body created by European governments to distribute its grant money in Russia and avoid paying heavy state taxes.

The offer has been made to INTAS - the International Association for the Promotion of Co-operation with Scientists from the Independent States of the FSU - which was established by the member states of the European Union (plus Austria) in 1992.

ISF officials say they made the offer in recognition of the difficulties INTAS has faced in ensuring that funds reach the scientists for whom they are intended through official channels, without having either customs duties or income tax deducted.

They claim that many Russian scientists and colleagues in the West have become frustrated at the delays caused by these difficulties, and have offered the ISF's formal exemption from taxes, negotiated per- sonally by Soros with the Russian president Boris Yeltsin, as a way around the problem.

But INTAS officials have rejected the ISF offer. They claim that, in principle, the charitable status of their organization means that its grants are automatically exempt from taxes, and that recent negotiations with European and Russian banks have led to a new agreement on procedures for channelling funds directly to Russian scientists.

They also argue that their decision is a result of their more decentralized mode of operation. "It is our policy not to centralize things too much," says Pierre Vennay, the European organization's directorgeneral.

Russian legislation requires more than half of any grants sent into the country to be paid to the government in taxes and customs duties. INTAS member states refused to transfer funds under such conditions. "Our organization is not intended to support the Russian state," says Flemming Woldbye, chairman of the INTAS general assembly.

The difficulty has been compounded by doubts among scientists in both Russia and the West that money sent through formal channels will indeed arrive in the pockets of scientists untaxed, despite official reassurances to the contrary.

Vladimir Skulachev, chairman of the ISF Russian advisory council, says that making use of the ISF would enable INTAS to cut down on organizational costs, as well as to use the bulk discounts that the ISF has negotiated on the purchase of scientific equipment in the West.

But INTAS remains optimistic that it can solve the problem on its own. Vennay acknowledges that setting up the channels to transfer funds has been a lengthy and complex task, but says that money is now being transferred to Russian scientists on an experimental basis.

Furthermore, Woldbye says that at a recent meeting with INTAS managers, Boris Saltykov, the Russian Minister of Science, promised to discuss tax and customs duties with his colleagues in the Russian government.

Vladimir Pokrovsky 